\title{
Taalgebruik in die nywerheid
}

\author{
J.H. le Roux \\ Navorsings- en Ontwikkelingsdepartement, Sasol Tegnologie (Edms.) Bpk., Posbus 1, Sasolburg
}

Artikels oor taalgebruik in bepaalde sektore van die samelewing is gewoonlik gemik op vakterminologie. Ek wil egter van dié gebruik afwyk deur te skryf oor taal as kommunikasiemiddel in die breë sin, mondeling en skriftelik. In die proses wil ek 'n lansie breek vir Afrikaans.

In die nywerheid is daar 'n subtiele wisselwerking tussen mondelinge en skriftelike kommunikasie. Elk het sy voor- en nadele. Die gesproke woord is interaktief, dit bevorder ideeproduksie deur uitwisseling van gedagtes. Die geskrewe woord is meer eksak en daar kan altyd weer daarna terugverwys word. Alle fasette van die nywerheid berus op kommunikasie. Kommunikasievermoëns is dus belangrik wat vordering in 'n loopbaan in die nywerheid betref.

Probleme word dikwels opgelos deur 'n groep belanghebbendes wat inligting insamel, bespreek, sif, verwerk en interpreteer. Hierin is Afrikaans en Engels belangrike kommunikasiemiddels, want ondervinding het geleer dat ideeproduksie en spanbou floreer wanneer vrylik in albei landstale gedebatteer kan word. Daar is dus 'n saak uit te mak vir die aanleer van Afrikaans deur immigrante.

Vrygestelde dokumente is vertoonvensters vir die werk van individue en groepe. Die nywerheid beweeg al meer in die rigting van die produksie van kennis, en daar bestaan vandag selfs maatskappye met verslae, publikasies en patente as finale produkte, eerder as tasbare goedere. Die verbetering van die kwaliteit van hierdie produkte kan ' $n$ belangrike bydrae lewer tot hoër produktiwiteit. Ook hier speel Afrikaans 'n belangrike rol, aangesien 'n groot persentasie verslae daarin geskryf word. Hoewel die Afrikaanssprekende wetenskaplike of ingenieur, soos selfs sy eweknie in 'n land soos Duitsland, vandag gedwonge voel om in Engels te publiseer, kan sy vordering dus tog ook afhang van sy vermoë om Afrikaans te skryf. Dit geld veral vir verslagdoening binne 'n maatskappy.
Ek wil graag die beginsels van effektiewe kommunikasie behandel met die klem op geskrewe verslae, aangesien hierdie dokumente so 'n sentrale plek in die nywerheid beklee. Hierdie beginsels is egter universeel, en die meeste daarvan geld vir die klaskamer, onderhoude, vergaderings en skryfwerk. 'n Verslag staan naamlik op twee bene. In die eerste plek is dit onvergeeflik as 'n verslag nie korrek is nie, wat numeriese gegewens, taalgebruik en afwerking betref. Dit kan egter volkome korrek wees maar van min waarde, omdat dit onverstaanbaar of sonder trefkrag is.

\section{KORREKTHEID}

In die eerste plek is dit belangrik dat die regte inligting, en voldoende daarvan, verkry word. 'n Tegniek bekend as gedagtekartering (Engels ,,mind mapping") kan hiervoor toegepas word.' Daardeur word alle vertakkings van 'n onderwerp gevolg deur die stel van vrae. Probleemdefinisie is ook belangrik.

Ter wille van die korrekte oordrag van inligting en idees is dit belangrik dat die regte terme gebruik en die reëls van grammatika gevolg word. Die probleem is egter dikwels dat daar geen aanvaarde Afrikaanse terme in sekere gespesialiseerde gebiede of vir nuwe begrippe bestaan nie. Dit stel uitdagings aan spesialiste. Die Engelse term , driveability", byvoorbeeld, word in brandstoftegnologie gebruik om aan te dui hoe ' $n$ voertuig hom gedra wanneer dit deur 'n bepaalde brandstof aangedryf word. Dit gaan dus nie soseer om die bestuurder en die stuurwiel en ander kontroles nie. 'n Letterlike vertaling soos ,,bestuurbaarheid" sou dus minder eksak wees as 'n term soos ",aandrywingskwaliteit", wat ek graag wil voorstel. 'n Eenvoudiger term wat voorgestel is, is ,,rybaarheid".

Dikwels is stellings in verslae nie korrek nie omdat 
wette van die logika, eerder as taalreëls, oortree word. So iets kan gewoonlik reggestel word deur die verslag deur iemand anders te laat nasien.

\section{VERSTAANBAARHEID EN TREFKRAG}

Die beginsels van verstaanbaarheid word deeglik uiteengesit deur De Wet et al vir die klaskamersituasie. ${ }^{2}$ Hulle is verwerk om aan te pas by die vereistes vir verslae, soos hieronder kortliks saamgevat. Alle aspekte van verstaanbaarheid en trefkrag kan ingedeel word onder vyf ,,dimensies", soos volg:

\section{EENVOUD}

Onnodig lang woorde, sinne en paragrawe moet vermy word. Pogings word aangewend om hierdie aspek te kwantifiseer, bv. deur middel van Gunning se vaagheidsindeks (GVI), soos volg:

$$
\begin{aligned}
\text { GVI }= & \frac{\text { Totale aantal woorde }}{\text { Aantal sinne }}+\frac{\text { Aantal lang woorde }}{\text { Totale aantal woorde }} \\
& \times 100
\end{aligned}
$$

(, lang woorde" is dié met meer as twee lettergrepe).

Afrikaans bied hier 'n probleem, aangesien dit nie, soos Engels, toelaat dat samestellings van twee of meer woorde los geskryf word nie. 'n Samestelling soos ,hardewashidrogenasiereaktor" moet dus as een woord geskryf word. In die Romaanse tale word sulke lang samestellings vermy deur deurgaans van voorsetsels tussen los woorde gebruik te maak. Dit mag omslagtig lyk, maar dit het die voordeel dat hierdie tale besonder eksplisiet is. Selfs in Engels word gekla oor die opstapeling van woorde om een komplekse begrip weer te gee, al word hulle ook los geskryf. ,Reaktor vir die hidrogenasie van harde was" is volkome korrek en verstaanbaar, met verbande duidelik aangetoon.

Sommige mense dink dat hul ' $n$ indruk moet probeer maak met hoogdrawende, geleerde woorde. Die teendeel is egter waar, nl. dat bekende eenvoudige woorde meer trefkrag het. 'n Stukkie goeie raad is, in Engels gestel: ,"Try to express, not to impress."

\section{LOGIESE ORDE}

'n Goeie verslag is gestruktureerd, met 'n logiese ordening van begrippe in sinne en paragrawe. Daar is 'n ,,goue draad' wat deur die verslag loop, vanaf die stel van die oogmerke tot by die bereiking daarvan. Lang verslae word gewoonlik ingedeel in afdelings onder opskrifte. In 'n kort verslag, memorandum of brief is dit goed om te begin met 'n kort inleiding wat die oogmerke weergee. Direk daarna behoort die ver- naamste bevindinge weergegee te word, terwyl die res volg as ondersteuning daarvan. Ordening volgens begrippe word bevorder deur die indeling van die ingesamelde inligting in tabelvorm onder bepaalde kategorieë. Dit is slegs 'n voorlopige ordening en dui nie noodwendig op die finale indeling in die verslag nie.

\section{SAAKLIKHEID EN DOELGERIGTHEID}

Alle onnodige dinge word vermy. Deurentyd word die oogmerke, wat duidelik aan die begin gestel is, in gedagte gehou. Die skrywer het hom ingedink in die moontlike gevolge wat die lees van die verslag deur verskillende ontvangers kan hê. Spesifieke eerder as vae, algemene terme word gebruik.

\section{VERKRYGING VAN BETROKKENHEID}

Die skrywer het verseker dat die lesers die verslag wil lees. Dit spreek tot die verstand in die eerste plek. Die belangegebiede van verskillende lesers en hul behoefte aan inligting is in ag geneem. 'n Lewendige skryfstyl word gebruik. Die verslag is objektief en dus sonder vooroordeel geskryf. Die mate van persoonlikheid of onpersoonlikheid is aangepas by die situasie.

\section{INAGNEMING VAN VERMOËNS}

Die skrywer het verseker dat die lesers die verslag kan verstaan deur hul kennis, gebiede van spesialisasie en posisies in die betrokke organisasie(s) in ag te neem. Waar nodig, word lesers gehelp om dinge in verband te bring met mekaar. Verskillende lesers se behoefte aan besonderhede is in ag geneem, bv. deur sekere inligting eerder as bylaes aan te heg.

Akademici, beide in die natuur- en geesteswetenskappe, is miskien nie voldoende bewus van die belangrikheid van goeie kommunikasievermoëns in die nywerheid nie. Dit is veral die behoefte aan spanwerk wat dit noodsaak. Wat mense in die nywerheid betref, het ek probeer om aan te dui hoe belangrik opleiding in die skryf- en algemene kommunikasiekuns is. Kursusse is beskikbaar, maar hulle behoort aangepas te word by spesifieke behoeftes. Verder is kursusse waardeloos, tensy persone wat dit bywoon hulle daarop toelê om die nuwe kennis toe te pas.

\section{VERWYSINGS}

1. Addison, G. Research Writing. Kursus periodiek aangebied deur Addison, Smith \& Associates, Durban en Johannesburg.

2. De Wet, J.J., Monteith, J.L. de K. en Van der Westhuizen, G.J. (1981). Opvoedende Leer (Butterworths, Durban). 